\title{
Relationship Between Entrepreneurial Process and Success of Business of Entrepreneurs with Disability in Western Kenya, Kenya
}

\author{
Ojijo Nyabola Thomas, \\ Dr. Fredrick Aila, \\ Dr. Bando Christine, \\ Maseno University, Kenya
}

Doi:10.19044/esj.2019.v15n31p240 URL:http://dx.doi.org/10.19044/esj.2019.v15n31p240

\begin{abstract}
Anchored on Empowerment theory, the study adopted a crosssectional research design on the Relationship between entrepreneurial process and success of business of entrepreneurs with disability in Western Kenya, Kenya. The target population was 73 registered businesses of entrepreneurs with disability. Saturated sampling was used in this study. The respondents were 69 business owners, out of which 4 were used for piloting, being 5-10\% of sample size considered as a sufficient representation. Primary data were collected using structured questionnaires while secondary data were obtained through document review. The findings revealed that Entrepreneurial processes significantly contributed to business success $(\beta=.609, \mathrm{t}(69)=6.285$, $\mathrm{p}=.000)$ and accounted for $37.1 \%$ change in business success $\left(\mathrm{R}^{2}=0.371\right.$, $\mathrm{F}(1,67=39.496, \mathrm{p}=.000$. The study concluded that an increase in entrepreneurial processes and procurement affirmative action practices will lead to improved business success. The study recommends that entrepreneurship stakeholders and the government assist in improving procurement practices for the persons with disabilities so as to help them improve on their businesses. The study is expected to inform policy makers both entrepreneurship stakeholders and the government on how entrepreneurial process can be used as a tool in improving persons with disabilities access to procurement opportunities and how to empower them.
\end{abstract}

Keywords: Entrepreneurial Process, Procurement affirmative action

\section{Introduction}

Based on Moore's model (2004), the entrepreneurial process as a set of stages and events that follows one another. These stages are the idea or conception of the business, the event that triggers the operations, 
implementation and growth. The model goes ahead to highlights the critical factors that drive the development of the business at each stage. According to the model, entrepreneurial traits are shaped by personal attributes and environment. Therefore, the entrepreneurial traits of disabled people are derived from their physical weakness that restricts them from doing heavy tasks that other people do. Starting businesses of their own where they can earn a living from becomes a key option. There are the external influences surrounding the beginning of the business and its development. The influence the local environment has on the willingness of the entrepreneur to open a business matters a lot as well. Close proximity to schools and institution, access to technology and availability of financial resources combined contributes to the difficulty of an entrepreneurial process.

The entrepreneurial process is a methodical way of starting a new venture which involves four steps. The entrepreneur realizes, evaluates, and develops an opportunity by defeating forces of resistance (Dhenak, 2010). The four phases include identifying and evaluating and opportunity, developing a business plan, ascertaining resource needs, and managing the resulting enterprise (Barringer \& Ireland, 2010).Stage one of the entrepreneurial process deals with opportunity identification. An opportunity by definition is a favorable set of circumstances which creates a need for a new product, business, or service. Opportunity identification is the process by which the entrepreneur comes up with a prospective idea for a new venture. Identifying the opportunity is not simple and this is where most disabled people tend to give up. Identification takes research, exploration, and evaluation of current needs, demands, and trends from consumers and others (Dhenak, 2010) and a considerable amount of money and resources that disabled people may lack.

The second stage is developing a business plan. Business plan development is an integral piece for submitting a proposal for an entrepreneurial or intrapreneurial business (Harjai, 2012). The organization or entrepreneur develops a description of the future direction of the business. A good business plan must be in place that displays a distinct opportunity (Harjai, 2012). The process in business plan formulation can be the most timeconsuming stage for the individual entrepreneur.

The third stage is determining and allocating resources. Ascertaining resource needs is a requirement to opportunity and business plan implementation. Assessing the risks in association with insufficient or inappropriate resources must be set apart from useful ones (Harjai, 2012). Most disabled people are offered low income jobs in the employment sector and they may not be able to save huge amount of finances to as startup capital. Obtaining the sufficient resources required to move forward with the business hinders the entrepreneurial success of most of the disabled persons. Where financial resources seem difficult to get, entrepreneurs employ non-financial 
resources such as crafts and skills. Most of the disabled people who have physical impairments may not be able to employ non-financial resources as well.

The fourth stage is managing the enterprise. Once resources are secure with the entrepreneurial process and the business plan, implementation can then take place. Managing the business means examining operational issues that will occur when implementation begins and throughout the entire business plan cycle (Barringer \& Ireland, 2010). The management process involves implementing structure and business style while determining variables for success (Harjai, 2012). Establishing a control system to identify and resolve any problem areas will help the management process. Lack of experience can give a disabled entrepreneur issues with business growth and administration (Harjai, 2012). Organizations understand the business development, growth, and sustainability better than individuals in many cases because resources are easier to be mobilize and utilize as well as methods with strategic management and system development cycles (Harjai, 2012).

The final step in the entrepreneurial process is harvesting wherein, an entrepreneur decides on the future prospects of the business, that is in regard to its growth and development. Here, the actual growth is compared against the planned growth and then the decision regarding the stability or the expansion of business operations is undertaken accordingly, by an entrepreneur. The entrepreneurial process is to be followed, again and again, whenever any new venture is taken up by an entrepreneur, therefore, it's an ever-ending process.

\section{Empowerment Theory}

The roots of empowerment theory extend further into history and are linked to Marxist sociological theory. These sociological ideas have continued to be developed and refined through Neo-Marxist Theory (also known as Critical Theory). (Burton \& Kagan, 1996. Empowerment is a process by which individuals and groups gain power, access to resources, and control over their lives (Budeli, 2010). Robbins, Chatterjee and Canda (1998). The empowerment theory is acts as an agent of change in making communities learn to recognize conditions of inequality and injustice with the aim of taking action to increase the powers of those regarded as powerless (Budeli, 2010). Robbins, Chatterjee \& Canda (1998) assert that empowerment theory provides conceptualisations of social stratification and oppression. It identifies the personal and political barriers and dynamics that maintain oppression. It also offers value frameworks for promoting human empowerment and liberation. This is built on people's strengths, resilience and resources. Robbins, Chatterjee \& Canda (1998) highlighted the aims of empowerment as to provide conceptualisations of social stratification and oppression, identify the 
personal and political barriers and dynamics that maintain oppression, offer value frameworks for promoting human empowerment and liberation and identify practical strategies for overcoming oppression and achieving social justice, and to build on people's strength, resilience and resources. They argued that the dynamics of discrimination and oppression to people with disability is the key focus to encourage social action and have a pragmatic, social justice orientation. Empowerment theories are mainly to promote awareness of real life circumstances and actions that produce change. It is through change that people with disability can be liberated and live a non-barrier lifestyle.

People with disabilities in actual fact need to be empowered and their lives need to be taken care of. Hence, with the government intervention by providing benefits of equal rights, the disabled would also be able to contribute to the economic growth of a country (Osman, Rahim, Yusof, Zikrul \& Noor, 2014). Mpofu, Gasva, Gwembire and Mubika (2011) elucidate that people with disabilities and their families need to be empowered and take care of their needs in every sphere of their lives. One of the ways for effective economic empowerment for the disabled is by encouraging and supporting them in activities of their communities such as entrepreneurship. Entrepreneurship is significantly known as a contributing factor towards economic growth for both developed and developing countries. The involvement of people with disabilities in the entrepreneurial activity will help to improve their quality of life as well as making the Millennium Development goal of most developing countries achievable by reducing fifty percent of the poverty rate by 2015 (Rahim, Abidin, Ping, Alias \& Muhamad, 2014; Mpofu \& Shumba, 2013).

There are many ways in which entrepreneurs living with disabilities can gain financial support as a way of empowering them. According to Greve (2009) financial support might take the form of grants, loans, subsidised loans or loan guarantees to credit providers, tax credits, and exemption from business registration fees. Kitching (2014) is of the view that financing might be tied to purchasing specific equipment, skills training or attendance at events such as trade fairs or exhibitions or to the development and application of assistive technologies (ATs). Maziriri(2016) points out that most applicants do not know what is expected of them when making application to financial institutions for assistance and the Department of Trade and Industry has a business referral and information network website to assist entrepreneurs in this area.

A study was conducted by Kodithuwakku \& Rosa (2002) on the entrepreneurial process and economic success in a constrained environment. The study explored the role of the entrepreneurial process in the economic and business success of Sri Lankan villagers. An ethnographic and multipleembedded case study approach was adopted to explore their success. The findings revealed that entrepreneurial process were important in the successful 
entrepreneurs' emergence from an extremely unpromising and constrained environment. It further revealed that In achieving success, they were not much more innovative in identifying opportunities than the unsuccessful villagers. Rather, they were much more creative and persistent in finding ways to mobilize scarce resources. In particular, their ability to extract value from their social networks and contacts was a vital element in their struggle to accumulate more capital.

Kodithuwakku (1997) conducted a study on entrepreneurial process in an uniform context of rural farmers in Sri Lanka. The primary focus of this research was the role of entrepreneurship in the economic success of rural farmers in Sri Lanka. A Multiple Embedded Case-Study strategy was adopted. The findings of this study illustrated how entrepreneurial and managerial value extraction strategies, in a limited resource context, complement each other and demonstrate that the managerial function is an integral component of entrepreneurship. By distinguishing amongst the different tasks of the entrepreneurial and managerial functions, the findings also confirmed that these two functions are interdependent elements in influencing economic success. The findings also indicate that certain entrepreneurship and strategic management principles, which have been proven applicable for the affluent Western world, are also relevant to small-scale rural farmers in the third world context who might be expected to struggle in abject poverty in order to scrape an existence.

Nassif, Ghobril \& Silva (2010) did a study in Brazil on Understanding the entrepreneurial process: a dynamic approach. The aim of this study was to contribute to the enhancement of knowledge concerning entrepreneurial process dynamics through an understanding of the values, characteristics and actions of the entrepreneur over time. The study focused on personal attributes and developed a framework that showed the importance of affective and cognitive aspects of entrepreneurs and the way that they evolve during the development of their business.

Jack \& Anderson (2002) conducted a study in the United Kingdom on the effects of embeddedness on the entrepreneurial process. The paper used Giddens' theory of structuration to develop the conception of entrepreneurship as an embedded socio-economic process. A qualitative examination of the actions of rural entrepreneurs was done and it was found out that embeddedness plays a key role in shaping and sustaining business. Being embedded in the social structure creates opportunity and improves performance. Embedding enabled the entrepreneurs to use the specifics of the environment. Thus, both recognition and realisation of opportunity are conditioned by the entrepreneurs' role in the social structure. 
Kodithuwakku \& Rosa (2002), Kodithuwakku (1997), Nassif, Ghobril \& Silva (2010) and Jack \& Anderson (2002) all reveal that entrepreneurial process has a positive influence on success. They however differ on constructs of entrepreneurial process. For example, Kodithuwakku (1997) constructed entrepreneurial process as managerial function whereas Nassif, Ghobril \& Silva (2010) constructed entrepreneurial process as the values, characteristics and actions of the entrepreneur over time. Jack \& Anderson (2002) on the other hand used Giddens' theory of structuration to develop the conception of entrepreneurship as an embedded socio-economic process. The reviewed studies have not analyzed the critical elements of entrepreneurial process all together which are screening, assembling, development and managing the enterprise, and therefore, information on the relationship between entrepreneurial process with its constructs considered together and success of business of entrepreneurs with disability in Western Kenya, remains unknown.

\section{Findings}

The study sought to carry out a summary analysis of entrepreneurial process using the four steps or dimensions that were; entrepreneurial screening, entrepreneurial resources, entrepreneurial development and management of the enterprises. An overview of the means, minimum values, maximum values sum standard deviations as well as variances on entrepreneurial process constructs are presented as shown in Table 1.

Table 1: Summary of Entrepreneurial Process

\begin{tabular}{llllllll}
\hline & $\mathbf{N}$ & $\begin{array}{l}\text { Minimu } \\
\mathbf{m}\end{array}$ & $\begin{array}{l}\text { Maximu } \\
\mathbf{m}\end{array}$ & Sum & Mean & $\begin{array}{l}\text { Std. } \\
\text { Deviation }\end{array}$ & Variance \\
\hline $\begin{array}{l}\text { Mean Entrepreneurial } \\
\text { Screening }\end{array}$ & 69 & 2.33 & 5.00 & 273.50 & 3.96 & .52 & .27 \\
$\begin{array}{l}\text { Mean Entrepreneurial } \\
\begin{array}{l}\text { Resources } \\
\text { Mean Entrepreneurial }\end{array}\end{array}$ & 69 & 1.17 & 4.17 & 198.33 & 2.87 & .67 & .44 \\
$\begin{array}{l}\text { Development } \\
\text { Mean Management of }\end{array}$ & 69 & 2.67 & 4.33 & 234.33 & 3.39 & .45 & .20 \\
Enterprise & 69 & 2.67 & 5.00 & 269.33 & 3.90 & .46 & .21 \\
Mean of entrepreneurial process & 69 & 2.67 & 4.50 & 243.88 & 3.53 & .38 & .15 \\
Valid N (listwise) & 69 & & & & & & \\
\hline
\end{tabular}

Source: Research Data,2019.

The findings indicate that the overall sample size of the entire number of the registered entrepreneurs with disabilities were 69. Entrepreneurial screening (ES) had a mean of 3.96, standard deviation of .52, variance of .27 and minimum and maximum values of 2.33 and 5.00 respectively. For entrepreneurial resources, the findings shows, minimum $=1.17$, maximum=4.17, sum=198.33, mean=2.87, std.dev $=.67$, variance $=.44$. Entrepreneurial development indicated minimum=2.67, maximum=4.33, 
sum $=234.33$, mean $=3.39$, std.dev.45, variance $=.20$. Finally, management of the enterprise had, minimum $=2.67, \quad$ maximum $=5.00, \quad$ sum $=269.33$, mean $=3.90$, std.dev $=.46$, variance $=.21$. The overall mean of entrepreneurial process was 3.53 with standard deviation of 0.38 . From these findings, it is clear that there were no standard deviation beyond one, and the means ranged between 2.8 and 3.9. This implies that the responses were concentrated around the mean and the views were not varied.

For this objective, the research hypothesis was: Ho: Entrepreneurial processes have no significant relationship with business success of entrepreneurs with disability in Western Kenya, Kenya. The study employed standard multiple linear regression models to analyze the objective. For causal effect, a standard multiple regression models were carried out. Business success was regressed against entrepreneurial process as indicated by the model. The findings are presented as shown in Table 2.

Table 2: Effect of Entrepreneurial Process on Business Success

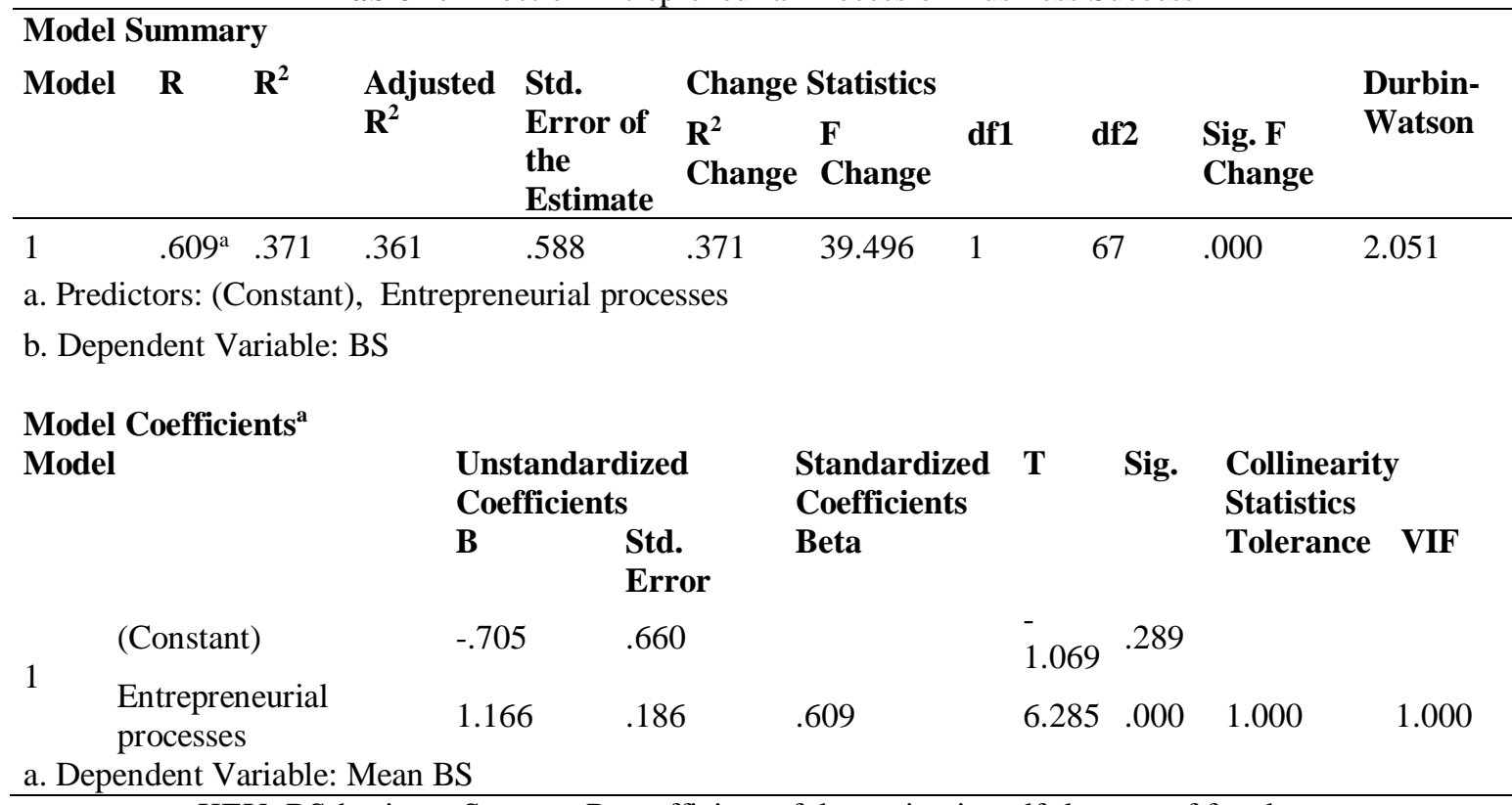

KEY: BS-business Success, R-coefficient of determination, df-degrees of freedom, B-unstandardized coefficient.

Source; Field Survey Data (2019)

The findings show that entrepreneurial processes accounted for $37.1 \%$ change in business success, $\mathrm{R}^{2}=37.1 \%, \mathrm{~F}(1,67)=39.496, \mathrm{p}=.000$, which reduced to $36.1 \%$ (Adjusted $\mathrm{R}^{2}=.361$ ) after controlling for an over-estimation in a shrinkage process. The findings on the model coefficients also indicate that entrepreneurial processes has a positive and significant effect on business success $\beta=.609, \mathrm{t}(69)=6.285, \mathrm{p}=.000$. This implies that I standard deviation in entrepreneurial processes will result in a change of 0.609 units in business 
success meaning that if more effort is put in entrepreneurial processes, then there will be improvement in business success.

In addition to the findings due to simple linear regression model, further analysis was carried out using standard multiple regression models on the effect of each of the entrepreneurial processes construct on business success. The findings are presented as shown in Table4.13. It is clear that entrepreneurial resource and entrepreneurial development accounted for a significant variance in business success. This is evident from the results that were significant, $\left(\Delta \mathrm{R}^{2}=.108, \mathrm{~F}(2,66)=8.415, \mathrm{p}=.005\right)$ for entrepreneurial resource and $\left(\Delta \mathrm{R}^{2}=.353, \mathrm{~F}(3,65)=46.830, \mathrm{p}=.000\right)$ for entrepreneurial development processes. From these findings, it is clear that both results were significant at $\mathrm{p}$ value less than or equal to 0.05 . However, the other forms of entrepreneurial processes did not account for a significant amount of variance in business success. In order to draw inference from the findings, the variance reported were multiplied by $100 \%$ so as to establish the variance accounted for by these processes out of 100 . The results indicate that entrepreneurial resources accounted for $10.8 \%$ leaving $88.2 \%$ of the variance in business success accounted for by other factors. Likewise, the results revealed that entrepreneurial development accounted for $35.3 \%$ variance in business success leaving $64.7 \%$ unaccounted or accounted for by other factors. It can therefore be deduced from these findings that entrepreneurial development accounts for the largest percentage of change in business success for businesses for entrepreneurs with disabilities.

Table 3. Standard Multiple Effect of Entrepreneurial Processes on Business Success

Model Summary

\begin{tabular}{|c|c|c|c|c|c|c|c|c|c|}
\hline \multirow{2}{*}{$\begin{array}{l}\text { Mode } \\
1\end{array}$} & \multirow[t]{2}{*}{$\mathrm{R}$} & \multirow[t]{2}{*}{ R Square } & \multirow{2}{*}{$\begin{array}{l}\text { Adjusted R } \\
\text { Square }\end{array}$} & \multirow{2}{*}{$\begin{array}{l}\text { Std. Error of } \\
\text { the Estimate }\end{array}$} & \multicolumn{5}{|c|}{ Change Statistics } \\
\hline & & & & & $\begin{array}{l}\text { R Square } \\
\text { Change }\end{array}$ & F Change & df1 & df2 & $\begin{array}{l}\text { Sig. F } \\
\text { Change }\end{array}$ \\
\hline 1 & $.220^{\mathrm{a}}$ & .048 & .034 & .723 & .048 & 3.407 & 1 & 67 & .069 \\
\hline 2 & $.395^{\mathrm{b}}$ & .156 & .130 & .686 & .108 & 8.415 & 1 & 66 & .005 \\
\hline 3 & $.714^{\mathrm{c}}$ & .509 & .487 & .527 & .353 & 46.830 & 1 & 65 & .000 \\
\hline 4 & $.731^{\mathrm{d}}$ & .535 & .506 & .517 & .025 & 3.498 & 1 & 64 & .066 \\
\hline
\end{tabular}

a. Predictors: (Constant), Entrepreneurial Success

b. Predictors: (Constant), Entrepreneurial Success, Entrepreneurial Resource

c. Predictors: (Constant), Entrepreneurial Success, Entrepreneurial Resource, Entrepreneurial Development

d. Predictors: (Constant), Entrepreneurial Success, Entrepreneurial Resource, Entrepreneurial Development, Enterprise Management

Model

Coefficients $^{\mathbf{a}}$

Unstandardized Standardized Coefficients T Coefficients 


\begin{tabular}{|c|c|c|c|c|c|c|}
\hline & & B & $\begin{array}{l}\text { Std. } \\
\text { Error }\end{array}$ & Beta & & \\
\hline \multirow{2}{*}{1} & (Constant) & 2.182 & .675 & & 3.234 & .002 \\
\hline & Entrepreneurial Success & .311 & .169 & .220 & 1.846 & .069 \\
\hline \multirow[b]{2}{*}{2} & (Constant) & 2.026 & .642 & & 3.155 & .002 \\
\hline & $\begin{array}{l}\text { Entrepreneurial Success } \\
\text { Entrepreneurial Resource }\end{array}$ & $\begin{array}{l}.048 \\
.417\end{array}$ & $\begin{array}{l}.184 \\
.144\end{array}$ & $\begin{array}{l}.034 \\
.377\end{array}$ & $\begin{array}{l}.262 \\
2.901\end{array}$ & $\begin{array}{l}.794 \\
.005\end{array}$ \\
\hline \multirow[b]{2}{*}{3} & (Constant) & -.101 & .583 & & -.173 & .863 \\
\hline & $\begin{array}{l}\text { Entrepreneurial Success } \\
\text { Entrepreneurial Resource } \\
\text { Entrepreneurial Development }\end{array}$ & $\begin{array}{l}-.182 \\
.122 \\
1.144\end{array}$ & $\begin{array}{l}.145 \\
.119 \\
.167\end{array}$ & $\begin{array}{l}-.128 \\
.110 \\
.703\end{array}$ & $\begin{array}{l}-1.250 \\
1.029 \\
6.843\end{array}$ & $\begin{array}{l}.216 \\
.307 \\
.000\end{array}$ \\
\hline \multirow[b]{2}{*}{4} & (Constant) & -.900 & .714 & & -1.260 & .212 \\
\hline & $\begin{array}{l}\text { Entrepreneurial Success } \\
\text { Entrepreneurial Resource } \\
\text { Entrepreneurial Development } \\
\text { Enterprise Management } \\
\text { ent Variable: Mean BS }\end{array}$ & $\begin{array}{l}-.111 \\
.099 \\
.961 \\
.309\end{array}$ & $\begin{array}{l}.148 \\
.117 \\
.191 \\
.165\end{array}$ & $\begin{array}{l}-.078 \\
.090 \\
.590 \\
.194\end{array}$ & $\begin{array}{l}-.749 \\
.847 \\
5.032 \\
1.870\end{array}$ & $\begin{array}{l}.456 \\
.400 \\
.000 \\
.066\end{array}$ \\
\hline
\end{tabular}

Source: Survey data,2019

The findings on the model coefficients indicate that only two variables had a significant effect on business success. These variables or processes are entrepreneurial resource and entrepreneurial development. This is evident from the findings which shows that entrepreneurial resources had a positive and significant effect $(\beta=.377, \mathrm{t}(69)=2.901, \mathrm{p}=.005)$ as well as entrepreneurial development, $(\beta=.590, \mathrm{t}(69)=5.032, \mathrm{p}=.000)$. This implies that when the entrepreneurial processes are compared and in-cooperated in the model, only entrepreneurial resources and development have an effect on business success with the later having the strongest effect.

Based on the findings obtained from the correlation as well as the regression model, it can be concluded that there is a relationship between entrepreneurial process and business success. Therefore we reject the null hypothesis that there is no relationship between entrepreneurial process and business success and adopt the alternative hypothesis that there is a relationship between entrepreneurial process and business success. It can thus be concluded that there is a positive relationship between entrepreneurial process and success of business of entrepreneurs with disability in Western Kenya, Kenya. According to McClelland the characteristics of entrepreneur has two features first doing things in a new and better way and second decision making under uncertainty. This confirms the extent to which they can carry out entrepreneurial development as well as management of their business as in the present study.

These present findings agree with those of Kodithuwakku and Rosa (2002), who found out that entrepreneurial process were important in the success of a business. Likewise, Nassif, Ghobril and Silva (2010), and Jack \& 
Anderson (2002) also reveal that entrepreneurial process has a positive influence on success. The construction of entrepreneurial processes is however different with all the mentioned authors. For example, Kodithuwakku (1997) constructed entrepreneurial process as managerial function whereas Nassif, Ghobril \& Silva (2010) constructed entrepreneurial process as the values, characteristics and actions of the entrepreneur over time. Jack \& Anderson (2002) on the other hand used Giddens' theory of structuration to develop the conception of entrepreneurship as an embedded socio-economic process. The contrast is also in the various different research designs used. Both Kodithuwakku and Rosa (2002) and Nassif, Ghobril and Silva (2010) use case study approach and Nassif, Ghobril \& Silva (2010) study takes a qualitative approach. None of the above authors analyzed the critical elements of entrepreneurial processes, which are screening, assembling, development and managing the enterprise. They also did not study the relationship between all these critical elements in composite on success. The current study revealed the relationship of the composite entrepreneurial processes on success $\beta=.609$, $\mathrm{t}(69)=6.285, \mathrm{p}=.000$ and also the various constructs which are entrepreneurial resources $\quad(\beta=.377, \mathfrak{t}(69)=2.901, p=.005)$ as well as entrepreneurial development, $(\beta=.590, \mathrm{t}(69)=5.032, \mathrm{p}=.000)$. Consequently, the effect of entrepreneurial processes alongside success of businesses of entrepreneurs with disability was established.

\section{Summary of findings}

The objective was to establish the relationship between entrepreneurial processes and success of business of entrepreneurs living with disability. The results revealed that the composite entrepreneurial process had a significant effect on business success leading to a positive change or improvement in business success, likewise for 2 constructs which were entrepreneurial resources and entrepreneurial development. Based on the research findings, it is concluded that entrepreneurial processes is practiced however the challenge is in the entrepreneurial resources which had the least mean and especially in the areas of sufficient capital and not enough sensitization seminars. Moreover, it is recommended that more effort be put in entrepreneurial resourcing with regards to capital and sensitization and also entrepreneurial development which had a low mean.

\section{References:}

1. Barringer, B.R., Jones F.F., Neubaun C, Donald O. (2005). A quantitative content analysis of the characteristics of rapid growth firms and their founders J. Bus.

2. Budeli, M. C. (2010). Barriers and coping capacities experienced by people living with 
3. Burton \& Kagan.(1996). Rethinking empowerment: shared action against powerlessness". compsy. org.uk. Retrieved 1 November 2017.

4. Greve, B. (2009). The labour market situation of disabled people in European countries and implementation of employment policies: a summary of evidence from country reports and research studies. Academic Network of European Disability Experts(ANED).

5. Harjai, K. J. (2012). Success of Business Plan Development Course Offered to Physicians

6. Kitching, J. (2014). Entrepreneurship and self-employment by people with disabilities.

7. Kodithuwakku, K. A. (1997). Entrepreneurial processes in an apparently uniform context: A study of rural farmers in Sri Lanka.

8. Kodithuwakku, S. S., \& Rosa, P. (2002). The entrepreneurial process and economic success in a constrained environment. Journal of Business Venturing, 17(5), 431-465

9. Kothari, C. (2004). Research Methodology, methods \& techniques $\left(2^{\text {nd }}\right.$ Ed.).New Delhi:

10. Kumar, R. (2011). Research methodology: A step by step for beginners $3^{\text {rd }}$ Edition: London: Sage Publication.

11. Landström, H. (2008). Entrepreneurship research: A missing link in our understanding of the knowledge economy. Journal of Intellectual Capital, 9(2), 301-322.

12. Moore, D (2004). The Basic Practice of statistics (3rdEd.)Freeman \& Co. New York.

13. Moore, D. P. (2000). Careerpreneurs: Lessons from Leading Women Entrepreneurs on Building a Career without Boundaries. Davies-Black Publishing, 3803 East Bayshore Road, Palo Alto, CA 94303.

14. Mpofu, Gasva, Gwembire \& Mubika (2011). Disabilities and entrepreneurship in Makonde rural community in Zimbabwe. Studies of Tribes and Tribals, 11(2), 135-144.

15. Mpofu, J., Gasva, D., Gwembire, J., \& Mubika, D. (2011). Introduction to Special Needs Education. Harare: Zimbabwe Open University.

16. Mugenda, O. M. and Mugenda, A. G.(2003). Research Methods: Quantitative and Qualitative Approaches, Acts Press, Nairobi-Kenya.

a. Nairobi: Government Printer.

17. Nassif, V. M. J., Ghobril, A. N., \& Silva, N. S. D. (2010). Understanding the entrepreneurial Psychometric theory, 2.process: a dynamic approach. BAR-Brazilian Administration Review, 7(2), 213226.

18. Osman, C. A., Rahim, H. L., Yusof, M. M., Noor, M. Z. H., Lajin, N. F. M., \& Jalaluddin, J. (2016). Empowering disabled youth with 
entrepreneurial values. In Proceedings of the ASEAN Entrepreneurship Conference 2014 (pp. 103-112). Springer, Singapore.

19. Pagán, R. (2009) 'Self-employment Among People with Disabilities: Evidence for Europe', Disability and Society, 24(2), 217-229.

20. Rahim, H. L., Abidin, Z. Z., Ping, S. D. S., Alias, M. K., \& Muhamad, A. I. (2014). Globalization and its effect on world poverty and inequality. Global Journal of Management and Business, 1(2), 8.

21. Republic of Kenya (2005). Public Procurement and Disposal Act, 2005. Nairobi:

22. Republic of Kenya (2010). Kenya Vision 2030. Nairobi: Government Printer.

23. Republic of Kenya (2010). The Constitution of Kenya. (2010). Nairobi: Government

24. Republic of Kenya. (2006). Public Procurement and Disposal Regulations 2006.

25. Republic of Kenya. (2013). Public Procurement Preference and Reservations (Amendment) Regulation. Nairobi: Government printer.

26. Robbins, S. P., Chatterjee, P., \& Canada, E. (1998). The nature of theories in Contemporary human behavior theory. 